\title{
2-Amino-5-sulfanyl-1,3,4-thiadiazoles: A new series of selective cyclooxygenase-2 inhibitors
}

\author{
RAJESH SHARMA* \\ JITENDRA SAINY \\ SUBHASH CHANDRA CHATURVEDI \\ School of Pharmacy, Devi Ahilya \\ Vishwavidyalaya, Takshshsila Campus \\ Khandwa Road, Indore, Madhya \\ Pradesh-452017, India
}

Accepted May 12, 2008

\begin{abstract}
A new series of cyclooxygenase-2 inhibitors with 2-amino-5-sulfanyl-1,3,4-thiadiazole as the central scaffold unit has been synthesized. The newly synthesized compounds were characterized by analytical and spectral methods. Compounds were screened for cyclooxygenase inhibitory activity by the colorimetric COX (ovine) inhibitor screening assay, anti-inflammatory activity by the carrageenean induced rat paw oedema test and analgesic activity by the tail flick method. Some compounds exhibited significant biological activity.
\end{abstract}

Keywords: 2-amino-5-sulfanyl-1,3,4-thiadiazoles, cyclooxygenase-1, cyclooxygenase-2, anti-inflammatory activity, analgesic activity

Suppression of pain and inflammation still continues to be a challenge despite the availability of a number of non-steroidal anti-inflammatory drugs (NSAIDs). This is because NSAIDs do not only exhibit a different spectrum of analgesic, anti-pyretic and anti-inflammatory effects but also cause gastrointestinal (GI) complications ranging from dyspepsia to fatal upper GI tract bleeding and perforation (1). Efforts to improve the adverse effect profile of the current NSAIDs have been focused on developing prodrugs (2) or modifications of marketed formulations (3). These approaches have been only partially successful. A recent approach is development of selective cyclooxygenase (COX)-2 inhibitors (4-6). COX is the key enzyme that catalyzes the conversion of arachidonic acid to prostaglandins and thromboxans. There are two types of cyclooxygenase enzymes, COX-1 and COX-2. Currently available NSAIDs inhibit both COX-1 and COX-2 enzymes. Inhibition of COX-1 reduces basal production of cytoprotective prostaglandins (PGs) PGE2 and PGI2 and hence causes ulceration while inhibition of COX-2 inhibits inflammation. Complete inhibition of COX-1 is therefore not preferred and drugs that inhibit the COX-2 enzyme are better anti-inflammatory agents $(7,8)$.

Owing to the continuous efforts in exploring the structural insights to aid the design $(9,10)$ and synthesis of safer novel anti-inflammatory agents, 2-amino-5-sulfanyl-1,3,4-thiadiazole was identified as the central nucleus. To date, 2-amino-5-sulfanyl-1,3,4-thiadiazole derivatives have not been reported to exhibit anti-inflammatory and

*Correspondence, e-mail: rbsm73@yahoo.co.in 
analgesic activity. For this reason, it was thought worthwhile to synthesize a series of diaryl substituted 2-amino-5-sulfanyl-1,3,4-thiadiazole derivatives, and perform their pharmacological testing.

\section{EXPERIMENTAL}

Melting points were determined in an open capillary tube and were uncorrected. Purity of the compounds was checked on pre-coated silica gel G plates $(0.2 \mathrm{~mm}$ thickness, Merck, India) using iodine vapor as visualizing agent. Infrared spectra were recorded on a Perkin Elmer Paragon 1000 IR spectrometer (USA) and ${ }^{1} \mathrm{H}$ spectra were obtained on a Bruker DRX-300 MHz FT NMR spectrometer (USA). Mass spectra were recorded on a Jeol SX-102 mass spectrometer (Japan). Elemental analyses of the synthesized compounds were obtained on an Elemental Vario EL II /Carlo N 1108 (Italy). All the reagents used in the present work were of synthetic grade (Aldrich, Germany, Lancaster, UK).

The synthetic pathway is given in Scheme I (11) and characterization data of compounds are given in Table I.

\section{Synthesis of 4-[5-chlorophenylamino)-1,3,4-thiadiazole-2-yl-sulphanyl]-benzene sulphonamide (1)}

2-Amino-5-sulfanyl-1,3,4-thiadiazole (0.01 mol, $1.31 \mathrm{~g})$ was suspended in a minimum quantity of water and a sufficient quantity of $85 \% \mathrm{KOH}$ solution was added under stirring at room temperature. After a few minutes (5-10), the solution was brought to $0{ }^{\circ} \mathrm{C}$ in an ice bath and 4-chlorobenzene sulfonamide ( $\mathrm{ArCl})(0.01 \mathrm{~mol}, 1.92 \mathrm{~g})$ was added under vigorous stirring. The reaction mixture was checked by thin layer chromatography.<smiles>[R]c1ccc(Nc2nnc(Sc3ccc([R])cc3)s2)cc1</smiles>

ArCl: 4-chlorobenzene sulfonamide $(1,3,5,7,9,11,14,15)$ or 4-chlorobenzene sulfonylchloride $(\mathbf{2}, \mathbf{4}, \mathbf{6}, \mathbf{8}, \mathbf{1 0}, \mathbf{1 2}, \mathbf{1 3}) . \mathrm{Ar}_{1} \mathrm{Cl}$ : 1,4-disubstituted benzene [1,4-dichlorobenzene $(\mathbf{1}, \mathbf{2})$,

1-bromo-4-chlorobenzene $(3,4)$, 1-chloro-4-flurobenzene $(5,6)$, 1-chloro-4-methylbenzene $(7,8)$, 1-chloro-4-trifluromethylbenzene $(\mathbf{9}, \mathbf{1 0}), 1$-chloro-4-trichloromethylbenzene $(\mathbf{1 1}, \mathbf{1 2})$, 4-chlorobenzene sulfonylchloride (13, 14), 4-chlorobenzene sulfonamide (15) 


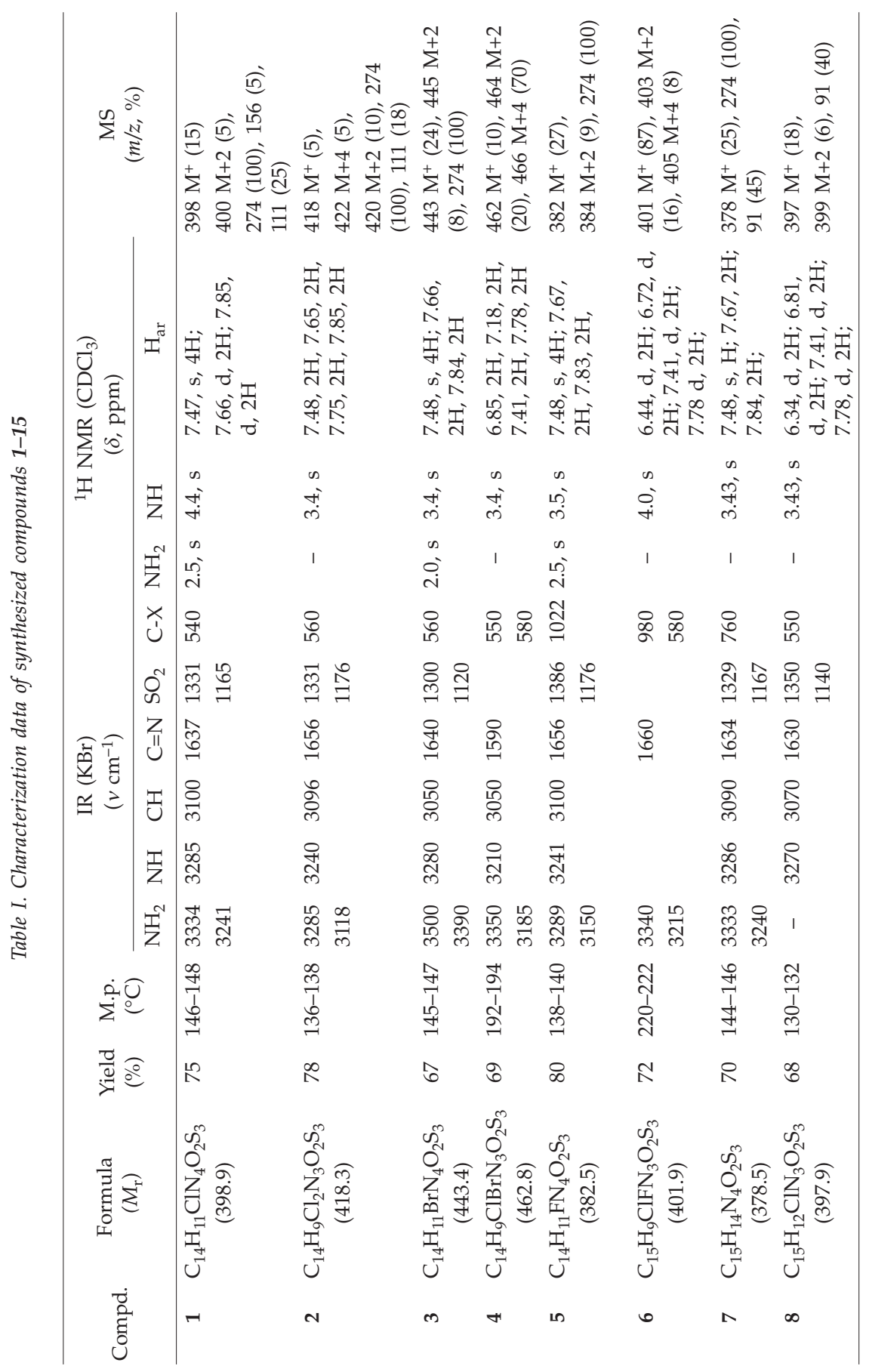




\begin{tabular}{|c|c|c|c|c|c|c|c|}
\hline 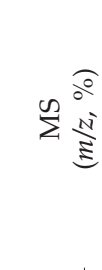 & 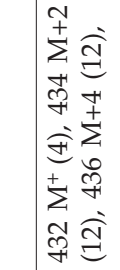 & & $\begin{array}{l}\widehat{\infty} \\
+ \\
\sum_{\infty} \\
\infty \\
\alpha\end{array}$ & 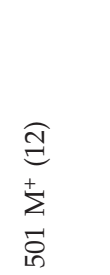 & 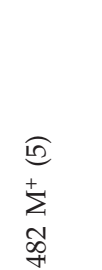 & 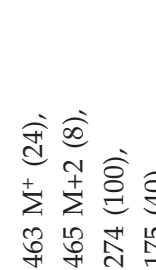 & 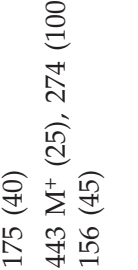 \\
\hline 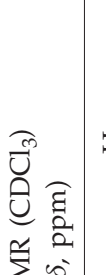 & $=$ & 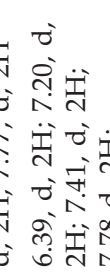 & 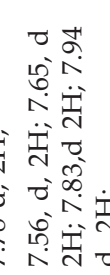 & 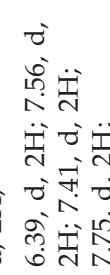 & 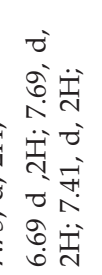 & 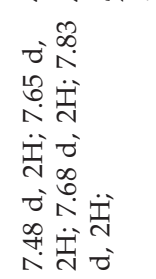 & 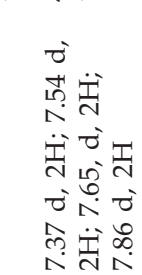 \\
\hline$\sum_{I} \sum_{I}$ & $\vec{z}$ & $\infty$ & on & के & م) & مึ & \\
\hline 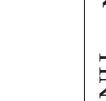 & |ี่ & & & & & & \\
\hline 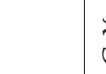 & 侅 & 兽 & $\stackrel{\vec{\sigma}}{\vec{\sigma}}$ & 品 & 点 & & \\
\hline$\delta$ & D. & 总 莺 & 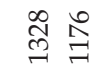 & 莺 吕 & 劵 & 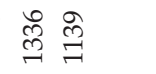 & \\
\hline & î & 㐘 & $\stackrel{\vec{\sigma}}{\underline{\sigma}}$ & : & 赤 & 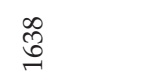 & 悉 \\
\hline & క & 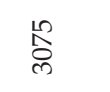 & 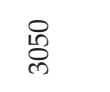 & 赤 & 总 & 命 & \\
\hline 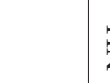 & 吾 胥 & 泥 & 胥 & 跑 & 总 & & \\
\hline 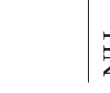 & $\begin{array}{ll}\mathbb{E} \\
\vec{c}\end{array}$ & 1 & 范 & 1 & ' & 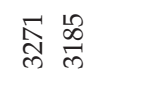 & 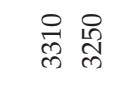 \\
\hline مُ & 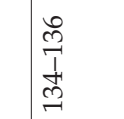 & $\begin{array}{l}\stackrel{\infty}{\vec{b}} \\
\stackrel{f}{7}\end{array}$ & $\begin{array}{l}\hat{0} \\
\overrightarrow{1} \\
\hat{0}\end{array}$ & 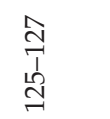 & 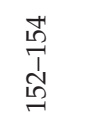 & 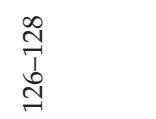 & $\vec{b}$ \\
\hline & 18 & $\stackrel{\infty}{\circledR}$ & $\stackrel{\infty}{\infty}$ & $\kappa$ & $\infty$ & $\infty$ & 8 \\
\hline 胥 & 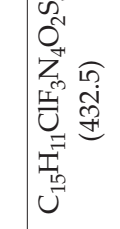 & 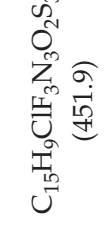 & 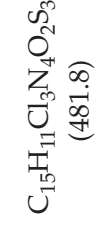 & 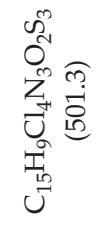 & 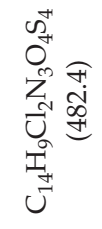 & 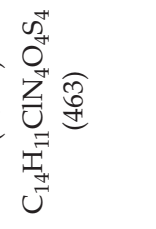 & 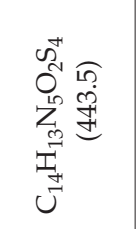 \\
\hline $\begin{array}{l}\text { के } \\
\text { हैं }\end{array}$ & $\sigma$ & 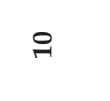 & $\Rightarrow$ & $\approx$ & 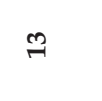 & $I$ & \\
\hline
\end{tabular}


The solution was neutralized upon completion of the reaction. The precipitate of 4-[5-amino-(1,3,4)thiadiazole-2-yl-sulphanyl--benzene sulphonamide formed slowly. It was filtered, washed with distilled water and crystallized using ether as a solvent. The purity of the synthesized intermediate was ascertained by thin layer chromatography using a methanol and xylene mixture $(4: 6, V / V)$. The intermediate $(0.01 \mathrm{~mol} ; 2.88 \mathrm{~g})$ was dissolved in ether and 1,4-dichlorobenzene $(0.01 \mathrm{~mol}, 1.48 \mathrm{~g})$ was added under stirring while maintaining the temperature between $0-5^{\circ} \mathrm{C}$. After 30 minutes, water was added, and a precipitate was formed. Filtration of the compound and recrystallization from ether yielded compound $\mathbf{1}$. Compounds 2-15 were synthesized in a similar way.

\section{Colorimetric COX (ovine) inhibitor screening assay}

All synthesized compounds were evaluated for COX-1 and COX-2 inhibitory activity by the colorimetric COX (ovine) inhibitor screening assay (13). It utilizes the peroxidase component of cyclooxygenase. The peroxidase activity was assayed colorimetrically by monitoring the appearance of oxidized $N, N, N, N$-tetramethyl-p-phenylenediamine (TMPD) at $590 \mathrm{~nm}$. This assay measures the heme-catalyzed hydroperoxidase activity of ovine cyclooxygenase. The percentage of COX-1 and COX-2 inhibition is reported in Table II.

Table II. Structure and in vitro inhibition of COX-1 and COX-2 by compounds 1 to 15

\begin{tabular}{ccccr}
\hline \multirow{2}{*}{$\begin{array}{c}\text { Compd. } \\
\text { No. }\end{array}$} & & $\mathrm{R}$ & $\mathrm{R}_{1}$ & \multicolumn{2}{c}{ Inhibition (\%) } \\
\cline { 4 - 5 } & & & $\mathrm{COX}-1^{\mathrm{b}}$ & \multicolumn{1}{c}{$\mathrm{COX}-2^{\mathrm{a}, \mathrm{b}}$} \\
\hline $\mathbf{1}$ & $-\mathrm{SO}_{2} \mathrm{NH}_{2}$ & $-\mathrm{Cl}$ & $97.17 \pm 0.01$ & $3.43 \pm 0.02$ \\
$\mathbf{2}$ & $-\mathrm{SO}_{2} \mathrm{Cl}$ & $-\mathrm{Cl}$ & $100.00 \pm 0.03$ & $87.85 \pm 0.04$ \\
$\mathbf{3}$ & $-\mathrm{SO}_{2} \mathrm{NH}_{2}$ & $-\mathrm{Br}$ & $56.50 \pm 0.03$ & $12.15 \pm 0.02$ \\
$\mathbf{4}$ & $-\mathrm{SO}_{2} \mathrm{Cl}$ & $-\mathrm{Br}$ & $70.12 \pm 0.01$ & $60.74 \pm 0.01$ \\
$\mathbf{5}$ & $-\mathrm{SO}_{2} \mathrm{NH}_{2}$ & $-\mathrm{F}$ & $-41.24 \pm 0.03$ & $14.95 \pm 0.04$ \\
$\mathbf{6}$ & $-\mathrm{SO}_{2} \mathrm{Cl}$ & $-\mathrm{F}$ & $100.00 \pm 0.02$ & $100.00 \pm 0.01$ \\
$\mathbf{7}$ & $-\mathrm{SO}_{2} \mathrm{NH}_{2}$ & $-\mathrm{CH}_{3}$ & $-91.52 \pm 0.01$ & $22.74 \pm 0.03$ \\
$\mathbf{8}$ & $-\mathrm{SO}_{2} \mathrm{Cl}$ & $-\mathrm{CH}_{3}$ & $100.00 \pm 0.01$ & $100.00 \pm 0.01$ \\
$\mathbf{9}$ & $-\mathrm{SO}_{2} \mathrm{NH}_{2}$ & $-\mathrm{CF}_{3}$ & $-119.25 \pm 0.02$ & $8.10 \pm 0.01$ \\
$\mathbf{1 0}$ & $-\mathrm{SO}_{2} \mathrm{Cl}$ & $-\mathrm{CF}_{3}$ & $100.00 \pm 0.03$ & $100.00 \pm 0.02$ \\
$\mathbf{1 1}$ & $-\mathrm{SO}_{2} \mathrm{NH}_{2}$ & $-\mathrm{CCl}_{3}$ & $-85.87 \pm 0.03$ & $-20.87 \pm 0.02$ \\
$\mathbf{1 2}$ & $-\mathrm{SO}_{2} \mathrm{Cl}$ & $-\mathrm{CCl}_{3}$ & $100.00 \pm 0.04$ & $100.00 \pm 0.03$ \\
$\mathbf{1 3}$ & $-\mathrm{SO}_{2} \mathrm{Cl}$ & $-\mathrm{SO}_{2} \mathrm{Cl}$ & $100.00 \pm 0.03$ & $100.00 \pm 0.02$ \\
$\mathbf{1 4}$ & $-\mathrm{SO}_{2} \mathrm{NH}_{2}$ & $-\mathrm{SO}_{2} \mathrm{Cl}$ & $-110.17 \pm 0.03$ & $42.36 \pm 0.01$ \\
$\mathbf{1 5}$ & $-\mathrm{SO}_{2} \mathrm{NH}_{2}$ & $-\mathrm{SO}_{2} \mathrm{NH}_{2}$ & $100.00 \pm 0.01$ & $100.00 \pm 0.02$ \\
Indomethacin & - & - & $100.00 \pm 0.02$ & $97.00 \pm 0.01$ \\
Celecoxib & - & - & 0.00 & $100.00 \pm 0.01$ \\
\hline
\end{tabular}

a $0.1 \mathrm{nmol}$ applied

b Mean \pm SEM, $n=3$. 
The inhibitory activity was measured on a Bio Rad 550 (India) plate reader, on a plate consisting of ninety wells. First, three wells were marked as background wells, then three wells were marked as $100 \%$ initial activity wells and the remaining fifty-one wells were marked as inhibitor wells. To the background wells, $160 \mu \mathrm{L}$ buffer $(0.1 \mathrm{~mol}$ $\mathrm{L}^{-1}$ Tris $\left.\mathrm{HCl}, \mathrm{pH} 8\right), 10 \mu \mathrm{L}$ heme and $10 \mu \mathrm{L}$ DMSO were added; $150 \mu \mathrm{L}$ buffer, $10 \mu \mathrm{L}$ heme, $10 \mu \mathrm{L}$ DMSO and $10 \mu \mathrm{L}$ of COX-1 enzyme were added to $100 \%$ initial activity wells; $150 \mu \mathrm{L}$ buffer, $10 \mu \mathrm{L}$ heme, $10 \mu \mathrm{L}$ of COX-1 and $10 \mu \mathrm{L}$ of $10 \mathrm{~m} \mathrm{~mol} \mathrm{~L}-1$ solution of test compound 1 in DMSO were added to the other three wells. In the same manner, the remaining forty-eight wells were prepared for test compounds 2 to 15, indomethacin and celecoxib, respectively. The plate was carefully shaken for a few seconds and incubated for 5 minutes at $25^{\circ} \mathrm{C}$. Finally, $20 \mu \mathrm{L}$ TMPD and $20 \mu \mathrm{L}$ arachidonic acid were added to all fifty-seven wells. The plate was shaken again and incubated for 5 minutes at $25^{\circ} \mathrm{C}$. The absorbance was noted at $590 \mathrm{~nm}$ and percentage inhibition was calculated. The procedure was repeated three times.

The COX-2 inhibitory activity was determined as discussed above; here COX-2 enzyme was used instead of COX-1 enzyme.

\section{Anti-inflammatory activity}

Anti-inflammatory activity of all synthesized compounds was determined by the carrageenean-induced rat paw oedema test as described by Winter et al. (14). Albino rats of Wistar strain (150-200 g) of both sexes were divided into different groups (control, test and standard) containing six animals each. The animals were housed in standard polypropylene cages under standard laboratory conditions (12:12 hour light/dark cycle at $25 \pm 2{ }^{\circ} \mathrm{C}$ ). They had free access to standard commercial diet and water. Ethical guidelines for the investigations of animals used in experiments were followed in all tests and the institutional Ethical Committee Approval was provided. The test and standard compounds were suspended in $1 \%$ carboxymethyl cellulose and administered orally to each animal using a gastric gavage needle. The control group animals, however, received the same volume of vehicle ( $1 \%$ carboxymethyl cellulose). One hour after the compounds were administered, carrageenean was injected into the subplantar surface of the right hind paw of animals. In this study, the animals were administered a $56 \mathrm{mg} \mathrm{kg}^{-1}$ (body mass) dose of the test drug and $10 \mathrm{mg} \mathrm{kg}^{-1}$ (body mass) dose of the standard drug indomethacin. The paw volume was measured immediately using a plethysmometer (initial paw volume) and thereafter the paw volume was measured 3 hours and 6 hours after the administration of carrageenean. Percent paw oedema inhibition is reported in Table III.

\section{Analgesic activity}

The analgesic activity was measured by the tail flick method (15), using a radiant type analgesiometer. The basal reaction time to radiant heat was taken by placing the tip of the tail on the radiant heat source. Swiss albino mice (25-30 g) of either sex were divided into seventeen groups containing six animals each. Animals were housed in standard polypropylene cages under standard laboratory conditions (12:12 hour light/dark cycle at $25 \pm 2{ }^{\circ} \mathrm{C}$ ). They had free access to standard commercial diet and water. For each animal, the tail flick reaction time was obtained thrice before drug administration and 
R. Sharma et al:: 2-Amino-5-sulfanyl-1,3,4-thiadiazoles: A new series of selective cyclooxygenase-2 inhibitors, Acta Pharm. 58 (2008) $317-326$.

Table III. Anti-inflammatory activity of synthesized compounds 1 to 15 on carrageenen induced rat paw edema

\begin{tabular}{ccc}
\hline $\begin{array}{c}\text { Compd. } \\
\text { No. }\end{array}$ & $\begin{array}{c}\text { Inhibition of paw oedema } \\
\text { after } 3 \text { hours }(\%)^{\mathrm{a}, \mathrm{b}}\end{array}$ & $\begin{array}{c}\text { Inhibition of paw oedema } \\
\text { after 6 hours }(\%)^{\mathrm{b}}\end{array}$ \\
\hline Control & - & - \\
\hline $\mathbf{1}$ & $15.11 \pm 0.02$ & $10.41 \pm 0.01$ \\
$\mathbf{2}$ & $46.51 \pm 0.01$ & $34.37 \pm 0.01$ \\
$\mathbf{3}$ & $23.25 \pm 0.01$ & $16.66 \pm 0.02$ \\
$\mathbf{4}$ & $38.37 \pm 0.02$ & $31.25 \pm 0.01$ \\
$\mathbf{5}$ & $26.74 \pm 0.02$ & $20.83 \pm 0.02$ \\
$\mathbf{6}$ & $61.62 \pm 0.02$ & $47.91 \pm 0.02$ \\
$\mathbf{7}$ & $41.86 \pm 0.01$ & $34.37 \pm 0.02$ \\
$\mathbf{8}$ & $65.11 \pm 0.01$ & $44.79 \pm 0.02$ \\
$\mathbf{9}$ & $18.60 \pm 0.02$ & $13.54 \pm 0.02$ \\
$\mathbf{1 0}$ & $61.62 \pm 0.01$ & $52.08 \pm 0.02$ \\
$\mathbf{1 1}$ & 00.00 & $-4.16 \pm 0.01$ \\
$\mathbf{1 2}$ & $65.11 \pm 0.01$ & $44.79 \pm 0.01$ \\
$\mathbf{1 3}$ & $61.62 \pm 0.02$ & $41.66 \pm 0.02$ \\
$\mathbf{1 4}$ & $53.48 \pm 0.02$ & $47.91 \pm 0.03$ \\
$\mathbf{1 5}$ & $63.95 \pm 0.01$ & $50.00 \pm 0.01$ \\
Indomethacin & $76.74 \pm 0.01$ & $58.33 \pm 0.02$ \\
\hline
\end{tabular}

a Dose for 1-15: $56 \mathrm{mg} \mathrm{kg}^{-1}$ b.m.

Dose for indomethacin $10 \mathrm{mg} \mathrm{kg}^{-1}$ b.m.

$\mathrm{b}$ Mean \pm SEM, $n=6$.

the mean was used as the pre-drug reaction time. After administration of the drug, the tail flick reaction times were measured after 30, 60, 90 and 180 minutes. The first group served as control and the animals were administered the vehicle (10\% Tween 20$)$. The second group of animals was administered $22.8 \mathrm{mg} \mathrm{kg}^{-1}$ (body mass) standard drug (tramadol hydrochloride). The animals of the third to seventeenth group were treated with $30 \mathrm{mg} \mathrm{kg}^{-1}$ (body mass) dose of the test drugs 1-15. Increase in the tail flick reaction time after the administration of test drugs and standard drug were calculated for 30, 60, 90 and 180 minutes (Fig. 1).

\section{RESULTS AND DISCUSSION}

2-Amino-5-sulfanyl-1,3,4-thiadiazole reacted with potassium hydroxide to afford a water soluble weak salt with an electron rich center and reacted with electron deficient 4-chlorobenzene sulphonamide to yield the intermediate 4-(5-amino-[1,3,4]-thiadiazole- 


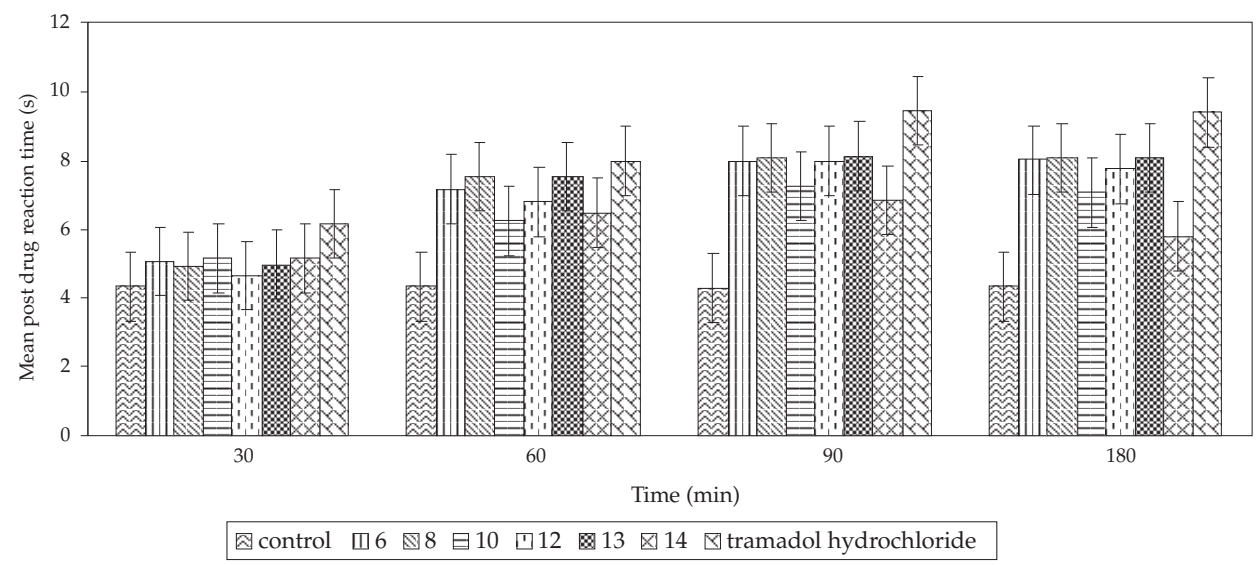

Fig. 1. Analgesic activity (tail flick) (mean post drug reaction \pm SEM, $n=6$ ).

-2-yl-sulphanyl)-benzene sulphonamide. The reaction was slow at the initial stage but the formation of $\mathrm{KCl}$ enhanced the reaction rate. The intermediate was then subjected to electrophillic substitution reaction with the electron deficient moiety 1,4-dichlorobenzene. It afforded compound 1 and similarly compounds 2-15 (11). Elemental analyses data and spectral data of all the synthesized compounds are in agreement with the assigned structure (Table I).

In vitro inhibition of COX-1 and COX-2 enzyme data (Table II) indicate that compounds 5, 7, 9 and 14 were selective inhibitors of COX-2 and potentiated the activity of COX-1 enzyme (16). Among the above four compounds, 14 showed the highest selective inhibitory activity against COX-2 enzyme (42.4\%). All the four compounds possess the sulphonamide group, which is in agreement with the established fact that sulphonamide group is a required pharmacophore for selective inhibition of COX-2 enzyme. However, compounds $6,8,10,12,13$ and 15 showed non-selective COX inhibitory activity; they showed 100\% inhibition against COX-1 and COX-2 enzymes. Compounds 1, 2, 3 and 4 showed selective inhibitory activity against COX-1 enzymes. The percentage inhibition of COX- 1 and COX-2 by compound 2 is comparable to that of the standard drug indomethacin. Most interesting activity was found in compounds $\mathbf{1 1}$ and $\mathbf{1 2}$. Compound $\mathbf{1 1}$ was found to potentiate the activity of COX-1 and COX-2 enzymes while replacement of $-\mathrm{SO}_{2} \mathrm{NH}_{2}$ in $\mathbf{1 1}$ by $-\mathrm{SO}_{2} \mathrm{Cl}$ in $\mathbf{1 2}$ made it a non-selective COX inhibitor.

Inflammation induced by carrageenean involves three distinct phases of mediator release, including serotonin and histamine in the first phase (0-2 hours), kinins in the second phase ( 3 hours) and prostaglandin in the third phase (0-4 hours). The results of this study indicate that compounds $6,8,10,12,13$ and 14 protected the paw oedema in rat by 54 to $65 \%$ after 3 hours and 45 to $52 \%$ after 6 hours, while other tested compounds showed lower anti-inflammatory activity compared to indomethacin (Table III). This suggests that the presence of $-\mathrm{SO}_{2} \mathrm{Cl}$ is also favorable for anti-inflammatory and analgesic activity. The same compounds showed analgesic activity comparable to that of tramadol hydrochloride (Fig. 1). 


\section{CONCLUSIONS}

Compound 14 \{4-[5-(4-sulfamoyl-phenylsulphanyl)-1,3,4-thiadiazole-2-yl-amino]benzene sulphonyl chloride\} can be selected for further studies since it contains sulphonamide as well as sulphonyl group; it showed the highest percentage of COX-2 inhibition and significant anti-inflammatory and analgesic activity compared to indomethacin and tramadol hydrochloride, respectively.

\section{REFERENCES}

1. M. C. Allison, A. G. Howastan, C. J. Torrance, F. D. Lee and R. N. Russell, Gastrointestinal damage associated with the use of nonsteroidal anti-inflammatory drugs, Engl. J. Med. 327 (1982) 749-754.

2. D. Bohl, H. Gaussmann, G. Vorberg, J. Sanch, R. Garcia-Barbal, J. F. Sarti and F. J. J. Harrison, A clinical trial comparing a new NSAID: Droxicam and proxicam in spinal osteoarthritis, Int. J. Clin. Pharmacol. Ther. Toxic. 28 (1990) 416-419.

3. R. S. Shelley and Y. Wei, Solutions of Aryl or Heteroaryl Substituted Alkanoic Acids in Lipophilic Solvents and Soft Gelatin Capsules Containing Such Solutions, Eur. Pat. Pub., 30 Nov. 1995, WO, 9531979, 1994.

4. K. Chegaev, L. Lazzarato, P. Tosco, C. Cena, E. Marini, B. Rolando, P. A. Carrupt, R. Fruttero and A. Gasco, NO-donor COX-2 inhibitors. New nitrooxy-substituted 1,5-diarylimidazoles endowed with COX-2 inhibitory and vasodilatory properties, J. Med. Chem. 50 (2007) 1449-1457; DOI: $10.1021 /$ jm0607247.

5. M. Biava, G. C. Porretta, G. Poce, S. Supino, S. Forli, M. Rovini, A. Cappelli, F. Manetti, M. Botta, L. Sautebin, A. Rossi, C. Pergola, C. Ghelardini, E. Vivoli, F. Makovec, P. Anzellotti, P. Patrignani and M. Anzini, Cyclooxygenase-2 inhibitors. 1,5-diarylpyrrol-3-acetic esters with enhanced inhibitory activity toward cyclooxygenase- 2 and improved cyclooxygenase-2/cyclooxygenase-1 selectivity, J. Med. Chem. 50 (2007) 5403-5411; DOI: 10.1021/jm0707525.

6. J. P. Waldo and R. C. Larock, The synthesis of highly substituted isoxazoles by electrophilic cyclization: An efficient synthesis of valdecoxib, J. Org. Chem. 72 (2007) 9643-9647; DOI: 10.1021/ jo701942e.

7. J. R. Vane, Inhibition of prostaglandin synthesis as a mechanism of action for aspirin-like drugs, Nature (New Biol.) 231 (1971) 232-235.

8. J. A. Mitchell, P. Akaraseenont, C. Themermann, R. J. Flower, J. R. Vane, Selectivity of non steroidal anti-inflammatory drugs as inhibitors of constitutive and inducible cyclooxygenase, Proc. Natl. Acd. Sci. USA. 90 (1993) 11693-11697.

9. R. Sharma and S. C. Chaturvedi, Development of pharmacophoric models on 5,6-diarylimidaxo[2,1-b]-thiazole for selective cyclooxygenase-2 inhibitors, Indian J. Pharm. Sci. 66 (2004) 758-772.

10. R. Sharma, S. C. Chaturvedi and A. K. Saxena, 3D-QSAR studies on novel terphenyls for selective inhibition of cyclooxygenase-2 enzyme, Indian J. Pharm. Sci. 66 (2004) 758-772.

11. F. Clerici and D. Pocar, Synthesis of 2-amino-5-sulfanyl-1,3,4-thiadiazole derivatives and evaluation of their antidepressant and anxiolytic activity, J. Med. Chem. 44 (2001) 931-936; DOI: 10. 1021/jm001027w.

12. R. J. Kulmacz and W. E. M. Lands, Requirements for hydro peroxide by the cyclooxygenase and peroxidase activities of prostaglandin H synthase, Prostaglandins 25 (1983) 531-540. 
13. Colorimetric COX (ovine) inhibitor screening assay, Catalog No. 760111, Cayman Chemical, Ann Arbor (MI) 2005.

14. C. A. Winter, E. A. Risely and G. N. Nuss, Carrageenean-induced edema in hind paw of the rat as an assay for anti-inflammatory drugs, Proc. Soc. Exp. Biol. 111 (1962) 544-547.

15. H. G. Vogel, Drug Discovery and Evaluation Pharmacological Assays, Springer, Frankfurt 2002, pp. 694.

16. R. R Ranatunge, M. Augustyniak, U. K. Bandarage, R. A. Earl, J. L. Ellis, D. S. Garvey, D. R. Janero, L. G. Letts, A. M. Martino, M. G Murty, S. K. Richardson, J. D. Schroeder, M. J. Shumway, S. W. Tam, A. M. Trocha and D. V. Young, Synthesis and selective cyclooxygenase-2 inhibitory activity of a series of novel, nitric oxide donor containing pyrazoles, J. Med. Chem. 47 (2004) 2180-2193; DOI: 10.1021/jm0302769.

$S A \check{Z} E T A K$

\section{2-Amino-5-sulfanil-1,3,4-tiadiazoli: Nova serija selektivnih inhibitora ciklooksigenaze-2}

RAJESH SHARMA, JITENDRA SAINY i SUBHASH CHANDRA CHATURVEDI

Sintetizirana je nova serija inhibitora ciklooksigenaze-2 s 2-amino-5-sulfanil-1,3,4-tiadiazolom. Novi spojevi karakterizirani su uobičajenim analitičkim i spektroskopskim metodama. Sintetiziranim spojevima ispitana je sposobnost inhibicije ciklooksigenaze kolorimetrijskim COX testom (goveđi COX), protuupalno djelovanje na edem šape induciran karageninom i analgetsko djelovanje metodom pomicanja repa. Neki su spojevi pokazali značajno biološko djelovanje.

Ključne riječi: 2-amino-5-sulfanil-1,3,4-tiadiazoli, ciklooksigenaza-1, ciklooksigenaza-2, protuupalno djelovanje, analgetsko djelovanje

School of Pharmacy, Devi Ahilya Vishwavidyalaya, Takshshsila Campus, Khandwa Road, Indore, Madhya Pradesh-452017, India 